\title{
FAKTOR-FAKTOR YANG MEMPENGARUHI PENERIMAAN DIRI ANAK BERKEBUTUHAN KHUSUS TUNA NETRA DI YAYASAN SAYAP IBU YOGYAKARTA
}

\author{
Iges Alda Alfatihah \\ Fakultas Psikologi \\ Universitas Ahmad Dahlan \\ Igesaldaalfatihah@gmail.com
}

\begin{abstract}
Abstrak
Anak berkebutuhan khusus adalah anak yang mengalami keterbatasan secara fisik dan mental, ciri-ciri dari penerimaan diri adalah adalah memililki pengahargaan yang nyata, memiliki keyakinan akan standar tanpa harus diperbudak oleh orang lain. Faktor yang mendukung penerimaan diri individu mempunyai kelebihan dalam pemahaman tentang diri sendiri untuk mengenali kemampuan dan ketidakmampuannya, semakin individu mengenali dirinya semakin mudah pula dalam menerima dirinya. Penerimaan individu dalam konsep diri yang positif yaitu individu yang dapat menerima fakta yang berbeda dengan dirinya dan dalam konsep yang negatif yaitu individu kurangnya rasa percaya diri yang mengakibatkan individu cenderung berbeda secara negatif.
\end{abstract}

Kata kunci: penerimaan diri, anak tunanetra, yayasan sosial

\section{PENDAHULUAN}

Patmonodewo (2003) mengemukakan bahwa defenisi dari anak berkebutuhan khusus adalah anak yang mengalami keterbatasan secara fisik dan mental, seperti sulit untuk melihat, mendengar, gangguan dalam berbicara, gangguan pada emosi yang berlebihan dan sulit dalam proses belajar. Mangunsong (2009) menyatakan bahwa pengertian dari anak berkebutuhan khusus yaitu anak yang dalam proses pertumbuhan atau perkembangan mengidap gangguan (fisik, mental-intelektual, sosial, emosional), dan membutuhukan pendidikan secara khusus.

Tunanetra merupakan kondisi dari mata karena adanya sesuatu yang tidak bisa berfungsi sebagaimana mestinya, sehingga mengalami ketidak mampuan untuk melihat dengan baik (Rudiyanti, 2001). Sardegna (2002) menyatakan bahwa tunanetra adalah individu yang mengalami kehilangan pada penglihatan karena kedua 
indera penglihatannya tidak berfungsi dengan baik seperti orang normal. Beberapa anak berkebutuhan khusus tunanetra beranggapan bahwa dirinya lemah sehingga membuatnya mengubah tatanan hidup yang ada pada dirinya, namun hal tersebut tidak berlaku bagi individu yang memiliki penerimaan diri. Salah satu faktor yang mempengaruhi penerimaan diri pada anak yang berkebutuhan khusus adalah berfkir positif, hal ini sejalan dengan pernyataan Tentama (2014) bahwa, ada hubungan yang sangat signifikan antara berpikir positif dengan penerimaan diri bagi difabel. Bagi difabel diharapkan dapat selalu menggunakan pola pikir yang positif dalam kehidupan sehari-hari agar dapat meningkatkan penerimaan dirinya sehingga difabel bisa menjalani kehidupan tanpa hambatan, pikiran serta emosi negatif dengan cara selalu berpandangan realistik maupun selalu mensyukuri setiap perubahan yang terjadi terhadap keadaan dirinya.

Berdasarkan latar belakang di atas, maka tujuan penulis adalah ingin mengetahui faktor yang mempengaruhi penerimaan diri serta dampak rendah dan dampak tingginya penerimaan diri bagi anak berkebutuhan khusus.

\section{PEMBAHASAN}

Menurut Sartain North, Strange, dan Chapman (1973) penerimaan diri merupakan kemauan untuk melihat diri seperti adanya, dan mengenali diri sebagaimana adanya. Penerimaan diri adalah suatu tingkatan kesadaran induvidu mengenai karakteristik pribadi dan adanya keinginan untuk hidup dengan keadaan tersebut (Hurlock, 1994). Penerimaan diri dapat didefinisikan sebagai rasa puas pada

diri sendiri, kualitas-kualitas pribadi, bakat sendiri, dan pengakuan akan keterbatasan sendiri (Chaplin, 2006).

Ciri-ciri individu dengan penerimaan diri menurut Jersild (1963) yaitu: mempunyai penghargaan yang nyata terhadap kelebihan yang ada pada dirinya, mempunyai keyakinan akan standar-standar dan prinsip-prinsip dirinya tanpa harus di perbudak oleh orang lain, mempunyai kemampuan untuk melihat dirinya secara fakta tanpa harus malu akan keadaannya, mampu mengenali kelebihan pada dirinya dan bebas menggunakannya. 
Hurlock (1978) menjelaskan ada beberapa faktor yang mendukung individu dalam penerimaan diri:

1) Pemahaman tentang diri sendiri yaitu adanya kepemahaman akan diri sendiri untuk mengenali kemampuan dan ketidak mampuannya, semakin orang bisa mengenali dirinya semakin mudah untuk menerima dirinya.

2) Pengharapan yang realistik yakni individu bisa menentukan sendiri kemauan yang disesuaikan dengan pemahaman dan kemampuannya, dan tidak diarahkan oleh orang lain sehingga pada saat mencapai tujuannya mempunyai harapan yang realistik.

3) Tidak adanya hambatan dalam lingkungan maksudnya yaitu seseorang yang sudah mempunyai keinginan yang realistik tetapi karna lingkungan disekitarnya tidak memberikan kesempatan maka individu akan sulit untuk mencapainya.

4) Sikap masyarakat yang menyenangkan yaitu masyarakat mempunyai dugaan yang baik karena adanya pujian terhadap kemampuan sosial dan kesediaan individu untuk mengikuti kebiasaan di lingkungan masyarakat.

5) Tidak adanya gangguan emosional yang berat yakni terciptanya individu yang mampu bekerja dengan sebaik mungkin dan merasa senang karena tekanan emosi sekecil apapun bisa mengganggu keseimbangan individu.

Sementara itu, menurut Tentama (2011) dalam hasil penelitiannya menemukan bahwa faktor inferioritas juga mempengaruhi penerimaan diri. Individu yang inferioritas rendah memiliki penerimaan diri yang tinggi.

Tentama (2010) mengungkapkan bahwa salah satu faktor yang mempengaruhi penerimaan diri individu adalah dengan berfikir positif. Individu yang berfikir positif akan cenderung merasa bersemangat, lebih mampu memahami dirinya, percaya akan kemampuannya, dan mantap menjalankan kehidupan, hal ini akan menjadikan indivdu akan semakin menerima keadaan di dalam dirinya. Dampak positif dari tingginya penerimaan diri pada individu adalah individu memiliki konsep diri positif, sehingga individu mampu memahami dan menerima perbedaan yang ada pada dirinya, mampu menyesuaikan diri dengan dengan seluruh pengalaman mentalnya dan mengevaluasinya (Calhoun \& Acocella, 1990). Sementara itu menurut Tentama 
(2012; 2012) individu yang memiliki penerimaan diri mampu menyesuaikan diri dengan lingkungannya dan memiliki dorongan untuk mengembangkan dirinya dengan kemampuannya. Menurut Dianawati, (2005) dampak negatif dari rendahnya penerimaan diri bagi individu adalah individu kurang memiliki rasa percaya diri, kurang mampu menerima kondisi dirinya, rendah diri, memiliki rasa malu yang berlebihan pada diri sendiri sehingga membuatnya untuk menyendiri atau mengasingkan diri.

\section{KESIMPULAN}

Kesimpulan yang bisa diambil adalah bahwa anak berkebutuhan khusus tersebut mengalami keterbatasan secara fisik dan mental, seperti sulit dalam melihat, mendengar, berbicara, gangguan pada emosi dan membutuhkan pendidikan secara khusus. Penerimaan diri merupakan keinginan untuk melihat diri sendiri seperti adanya dan mengenali diri sebagaimana adanya. Selain itu ciri-ciri dari penerimaan diri yakni memiliki penghargaan yang nyata, memiliki keyakinan akan standar tanpa harus diperbudak orang lain, dan mampu mengenali kelebihan pada dirinya. Adanya faktor yang mendukung dalam penerimaan diri individu mempunyai kelebihan dalam pemahaman tentang diri sendiri untuk mengenali kemampuan dan ketidakmampuannya, semakin orang mengenali dirinya semakin mudah pula dalam menerima dirinya, pengharapan yang realistik individu mampu mengarahkan sendiri keinginan yang disesuaikan dengan pemahaman dan kemampuannya, jika lingkungan tidak memberikan kesempatan maka individu sulit untuk mencapainya. Penerimaan diri berkaitan dengan konsep diri yang positif, individu dengan konsep diri yang positif dapat menerima fakta yang berbeda dengan dirinya dan penerimaan diri berkaitan dengan konsep diri yang negatif mengakibatkan kurangnya rasa percaya diri sehingga mengarahkan individu pada usaha mengisolasi dirinya sendiri dan akibatnya individu tersebut cenderung merasa berbeda secara negatif. 


\section{DAFTAR PUSTAKA}

Calhoun, J. F, \& Acocella, J. R., (1990). Psychology of adhustment and human relationship. New York: Mc GrawHill Publising Company.

Chaplin, J. P. (2006). Kamus lengkap psikologi. Jakarta: Raja Grafindo Persada.

Dianawati, Z. (2005). Perasaan inferioritas dan kompensasi remaja penyandang cacat fisik. Jurnal Ilmiah Psikologi Arkhe, 10(2), 119-136.

Efendi, M. (2006). Pengantar psikopedagogik anak berkelainan. Jakarta: Bumi Aksara.

Hurlock, E. (1978). Personality development. Tokyo: McGraw-Hill Publishing Company, Ltd.

Hulock, E. B. (1994). Psikologi perkembangan: Suatu pendekatan sepanjang rentang kehidupan. Jakarta: Erlangga.

Jersild, A. T. (1963). The psychology of adolescent. New York: The McMillan.

Mangunsong, F. (2009). Psikologi dan pendidikan anak berkebutuhan khusus. Depok: LPSP3.

Sardegna, J., Shelly, S., Rutzen, A. R., \& Steidl, S. M. (2002). The encyclopedia of blindness and vision impairement. New York: Facts on File, Inc.

Tentama, F. (2011). Hubungan inferioritas dan self-acceptance pada penyandang tuna daksa. Prosiding Seminar Nasional Hasil Peneluitian Dosen Wilayah V. Yogyakarta: Kopertis V. ISBN: 978-602-9367-04-1.

Tentama, F. (2010). Berpikir positif dan penerimaan diri pada remaja penyandang cacat tubuh akibat kecelakaan. Humanitas, 7(1), 66-75.

Tentama, F. (2012). Manfaat penerimaan diri bagi difabel. Republika, 69.

Tentama, F. (2012). Mencari sisi penerimaan diri difabel. Republika, Ed-1367.

Tentama, F. (2014). Hubungan positive thinking dengan self-acceptance pada difabel (bawaan lahir) di SLB negeri 3 Yogyakarta. Jurnal Psikologi Integratif, 2(2), 17.

Rudiyanti, R. (2001). Pendidikan anak tunanetra. Yogyakarta: Fakultas Ilmu Pendidikan Universitas Negeri Yogyakarta. 
Sartain, A. Q., North, A. J., Strange, J. R., \& Chapman, H. M. (1973). Psychology: Understanding human behavior. Singapore: McGraw Hill. 